\title{
Agglutination of "Streptococcus milleri" by lectins
}

\author{
J. T. C. KELLENS, J. A. JACOBS*, W. J. PEUMANS $\dagger$ and ELLEN E. STOBBERINGH
}

Department of Medical Microbiology, University of Limburg, Maastricht, Department of Medical Microbiology, University Hospital Maastricht, The Netherlands and $\dagger$ Laboratory of Phytopathology and Plant Protection, Catholic University Leuven, Belgium

\begin{abstract}
Summary. The agglutination of 218 clinical isolates and three ATCC type strains of "Streptococcus milleri" was tested with 25 different lectins from plants and fungi. An agglutination reaction with one or more lectins was observed with 42 isolates when the cells were untreated. After trypsinisation of the bacteria, 109 strains yielded a positive reaction and after boiling the bacterial cells at $\mathrm{pH} 2,218$ isolates were agglutinated. As an overall result of our experiments with untreated, trypsinised and boiled cells, 17, 37 and 45 different agglutination patterns, respectively, were obtained. The lectins from Datura stramonium, Robinia pseudoacacia and Dolichos biflorus agglutinated isolates belonging only to Lancefield group $\mathrm{C}$, being non-reactive with other isolates. These lectins were also found to be specific for "large colony type" streptococci of group C. The use of lectin agglutination in epidemiological and ecological studies of "S. milleri" is discussed.
\end{abstract}

\section{Introduction}

The species name "Streptococcus milleri" was first used in 1956 by Guthof to describe oral nonhaemolytic streptococcal species. ${ }^{1}$ Subsequently, the minute $\beta$-haemolytic and non-haemolytic streptococci referred to as the " $S$. milleri group" were included in this species. ${ }^{2}$ This heterogeneous group of streptococci was separated into different species by Facklam. ${ }^{3}$ On the basis of biochemical and genetic similarities, Coykendall et al. ${ }^{4}$ proposed grouping of these streptococci in a single species, $S$. anginosus. However, by means of DNA-DNA hybridisation studies, Whiley et al. recently revealed that there are three DNA homology groups in strains classified as $S$. anginosus. ${ }^{5}$ Therefore, they proposed the re-instatement of three distinct species- $S$. constellatus, $S$. intermedius and $S$. anginosus in the nomenclature ${ }^{6}$ However, the term "Streptococcus milleri", although not included in the approved list of bacterial names, ${ }^{7}$ is used widely in clinical microbiology to describe streptococci that are found in suppurative infections and thus have a clinical significance. $^{8}$

Strains belonging to the " $S$. milleri" group are heterogeneous: differences are found in many characteristics-including haemolysis, ${ }^{2}$ fatty acid fingerprinting, ${ }^{9}$ DNA base-pair ratios ${ }^{10}$ and cell-wall sugar composition. ${ }^{11}$ Furthermore, "S. milleri" strains can be differentiated serologically by their Lancefield group antigens (A, C, F or G), by Ottens type antigens (I, II, III or IV), or by both, but a significant number of strains remains untypable. ${ }^{2}$ Therefore, a typing system for these clinically important streptococci would be valuable for epidemiological and ecological studies.

In this report we describe the agglutination of 221 isolates of " $S$. milleri" by 25 different lectins from plants and fungi and discuss the usefulness of such a rapid, cheap and reliable typing method in epidemiological studies.

\section{Materials and methods}

\section{Bacterial strains}

In the period Jan. 1991-Dec. 1992, 218 clinical strains of " $S$. milleri" were isolated from 173 patients. Sites of isolation included the respiratory tract $(40$ strains), urogenital tract (24), blood (31), skin and soft tissues (35), abdominal cavity (26), pelvis (22) and other sites (40). Three type strains were obtained from the American Type Culture Collection (ATCC, Rockville, MD, USA): $S$. anginosus ATCC 33397, $S$. constellatus ATCC 27823 and S. intermedius ATCC 27335. The strains were stored at $-70^{\circ} \mathrm{C}$ in peptoneglycerol (proteose peptone no. 2, $1 \% \mathrm{w} / \mathrm{v}$; glycerin $8 \% \mathrm{v} / \mathrm{v})$.

\section{Lancefield grouping}

Lancefield grouping of strains into groups A, B, C, $F$ and $G$ was performed with the streptex latex agglutination kit (Wellcome Diagnostics, Dartford) according to the manufacturer's instructions. 
Table I. Lectins used in the agglutination assays

\begin{tabular}{|c|c|c|c|c|c|}
\hline No. & Code & Species name & Common name & $\begin{array}{l}\text { Carbohydrate } \\
\text { specificity }\end{array}$ & $\begin{array}{c}\text { Reference } \\
\text { no. }\end{array}$ \\
\hline 1 & PNA & Arachis hypogaea & Peanut & $\beta$-D-Gal $(1,3) \mathrm{D}-\mathrm{GalNAc}$ & 12 \\
\hline 2 & AMA & Arum maculatum & Lords and ladies & Complex & UP \\
\hline 3 & AMA II & Arum maculatum & Lords and ladies & Complex & UP \\
\hline 4 & APA & Aegopodium podagraria & Ground elder & D-GalNAc & 13 \\
\hline 5 & ASA & Allum sativum & Garlic & $\alpha(1,3)$ Man & 14 \\
\hline 6 & AUA & Allium ursinum & Ramsons & $\alpha(1,3) \mathrm{Man}, \alpha(1,6) \mathrm{Man}$ & 14 \\
\hline 7 & BDA & Bryonia dioica & White bryony & D-GalNAc & 15 \\
\hline 8 & DSA & Datura stramonium & Thorn-apple & D-(GlcNAc $)_{2}$ & 16 \\
\hline 9 & GNA & Galanthus nivalis & Snowdrop & $\alpha(1,3)$ Man & 14 \\
\hline 10 & IRA & Iris reticulatum & Iris & D-GalNAc & UP \\
\hline 11 & MAA & Maackia amurensis & Maackia & Neu5Ac- $\alpha(2,3) \mathrm{Gal}$ & 17 \\
\hline 12 & NPA & Narcissus pseudonarcissus & Daffodil & $\alpha(2,6)$ Man & 14 \\
\hline 13 & RPA & Robinia pseudoacacia & Black locus & Complex & 18 \\
\hline 14 & CCL & Ceratobasidium cornigerum & $\ldots$ & D-GalNAc & 19 \\
\hline 15 & RSA & Rhizoctonia solani & $\cdots$ & D-GalNAc & 19 \\
\hline 16 & SMyL & Sclerotinia myabaena & $\cdots$ & D-GalNAc & 20 \\
\hline 17 & SSL & Sclerotinia sclerotiorum & $\ldots$ & D-GalNAc & 20 \\
\hline 18 & SNA & Sambucus nigra & Elder & Neu $5 A c-\alpha(2,6)$ GalNAc & 21 \\
\hline 19 & SNA II & Sambucus nigra & Elder & D-GalNAc & 21 \\
\hline 20 & TL & Tulipa & Tulip & D-GalNAc & 22 \\
\hline 21 & WFA & Wisteria floribunda & Wisteria & D-GalNAc & 23 \\
\hline 22 & WGA & Triticum aestivum & Wheat germ & D-(GlcNAc), NeuNAc & 24 \\
\hline 23 & Con-A & Canavalia ensiformis & Jack bean & $\alpha$-D-Man, $\alpha$-D-Glc & 25 \\
\hline 24 & DBA & Dolichos biflorus & Horse gram & D-GalNAc & 26 \\
\hline 25 & VAA & Viscum album & Mistletoe & $\beta$-D-Gal & 27 \\
\hline
\end{tabular}

UP, unpublished.

\section{Lectins}

Lectins from different plants and fungi were extracted, isolated by affinity chromatography and further purified as described previously. ${ }^{12-27}$ The lectins are listed in table I, along with the scientific name and the common name of the species from which they were derived and their carbohydrate specificity. Lectin solutions of $1 \mathrm{mg} / \mathrm{ml} \mathrm{w} / \mathrm{v}$ in phosphatebuffered saline (PBS; $1.5 \mathrm{mM} \quad \mathrm{KH}_{2} \mathrm{PO}_{4}, 10 \mathrm{mM}$ $\mathrm{Na}_{2} \mathrm{HPO}_{4}, \mathrm{pH} 7 \cdot 4,3 \mathrm{~mm} \mathrm{KCl}, 140 \mathrm{~mm} \mathrm{NaCl}$ ) were stored at $-20^{\circ} \mathrm{C}$ until use.

\section{Agglutination assays}

Bacterial strains were grown in $50 \mathrm{ml}$ of ToddHewitt broth for $18 \mathrm{~h}$ at $37^{\circ} \mathrm{C}$ in air with $\mathrm{CO}_{2} 5 \% \mathrm{v} / \mathrm{v}$. Cells were collected by centrifugation at $3000 \mathrm{~g}$ for $15 \mathrm{~min}$, washed in PBS and resuspended in PBS; suspensions were adjusted to an $\mathrm{A}_{620}$ of 5 in a spectrophotometer.

Three $\mathrm{ml}$ of a suspension of each strain were left untreated, $3 \mathrm{ml}$ were treated with trypsin and $3 \mathrm{ml}$ were boiled in glycine- $\mathrm{HCl}$. Trypsin treatment was with trypsin $0 \cdot 1 \mathrm{mg} / \mathrm{ml} \mathrm{w} / \mathrm{v}$ for $1 \mathrm{~h}$ at $37^{\circ} \mathrm{C}$. After incubation, the cells were washed twice in PBS to remove the trypsin and resuspended in $3 \mathrm{ml}$ of PBS. For glycine- $\mathrm{HCl}$ treatment the cells were centrifuged at $3000 \mathrm{~g}$ for $15 \mathrm{~min}$, resuspended in $3 \mathrm{ml}$ of $0.25 \mathrm{M}$ glycine- $\mathrm{HCl}$ buffer, $\mathrm{pH} 2 \cdot 0$, and boiled for $15 \mathrm{~min}$. The cells were then washed with PBS and resuspended in $3 \mathrm{ml}$ of PBS.

Agglutination assays were performed as previously described $^{28}$ in small glass tubes in a final volume of $0.1 \mathrm{ml}$ containing $10 \mu \mathrm{l}$ of lectin solution and $90 \mu \mathrm{l}$ of cell suspension. A negative control was included for each strain by adding $10 \mu \mathrm{l}$ of PBS instead of lectin solution.

\section{Hapten inhibition test}

To test whether the agglutination reaction of the lectin was caused by its carbohydrate-binding capacity, inhibition of agglutination was tested with several sugars. Ten $\mu$ l of a carbohydrate solution ( $1 \mathrm{M}$ D-mannose, D-galactose, L-rhamnose, L-arabinose, Nacetyl-D-galactosamine, D-glucose, $\mathrm{N}$-acetylglucosamine or D-fucose; or mucin from porcine stomach $1 \mathrm{mg} / \mathrm{ml} \mathrm{w} / \mathrm{v}$ ) in PBS were added together with $10 \mu \mathrm{l}$ of the lectin solution to $80 \mu \mathrm{l}$ of cell suspension. After the mixtures had been left for $1 \mathrm{~h}$ at room temperature, agglutination was monitored visually.

\section{Reproducibility}

Reproducibility of lectin agglutination was tested with seven strains. Each strain was subcultured five times and the agglutination assays were performed as described above.

\section{Results}

Without pre-treatment of the bacteria, 42 strains agglutinated with one or more lectins (table II). The lectins PNA, APA, CCL, RSA and WFA gave the best 
Table II. Agglutination of untreated cells of different Lancefield groups with different lectins

\begin{tabular}{|c|c|c|c|c|c|c|c|c|c|c|c|c|c|c|c|c|c|c|}
\hline \multirow{2}{*}{$\begin{array}{l}\text { Lancefield } \\
\text { group }\end{array}$} & \multicolumn{17}{|c|}{ Number of strains that agglutinated with each lectin* } & \multirow{2}{*}{ Total } \\
\hline & 1 & 4 & 5 & 7 & 8 & 9 & 10 & 13 & 14 & 15 & 16 & 17 & 19 & 21 & 22 & 23 & 24 & \\
\hline A & 0 & 0 & 0 & 0 & 0 & 0 & 0 & 0 & 0 & 0 & 0 & 0 & 0 & 0 & 0 & 0 & 0 & 0 \\
\hline $\mathrm{C}$ & 0 & 4 & 0 & 0 & 7 & 0 & 0 & 13 & 10 & 10 & 0 & 2 & 10 & 14 & 5 & 0 & 11 & 15 \\
\hline $\mathrm{F}$ & 5 & 6 & 0 & 0 & 0 & 0 & 0 & 0 & 3 & 3 & 0 & 0 & 0 & 0 & 0 & 0 & 0 & 12 \\
\hline $\mathrm{G}$ & 0 & 1 & 0 & 0 & 0 & 0 & 0 & 0 & 1 & 1 & 0 & 0 & 0 & 0 & 0 & 0 & 0 & 1 \\
\hline NG & 9 & 3 & 0 & 0 & 0 & 0 & 0 & 0 & 0 & 0 & 0 & 0 & 0 & 0 & 0 & 3 & 0 & 14 \\
\hline Total & 14 & 14 & 0 & 0 & 7 & 0 & 0 & 13 & 14 & 14 & 0 & 2 & 10 & 14 & 5 & 3 & 11 & 42 \\
\hline
\end{tabular}

NG, not groupable.

* Numbers correspond to those in table I.

Table III. Agglutination of trypsin-treated cells of different Lancefield groups with different lectins

\begin{tabular}{|c|c|c|c|c|c|c|c|c|c|c|c|c|c|c|c|c|c|c|}
\hline \multirow{2}{*}{$\begin{array}{l}\text { Lancefield } \\
\text { group }\end{array}$} & \multicolumn{17}{|c|}{ Number of strains that agglutinated with each lectin* } & \multirow{2}{*}{ Total } \\
\hline & 1 & 4 & 5 & 7 & 8 & 9 & 10 & 13 & 14 & 15 & 16 & 17 & 19 & 21 & 22 & 23 & 24 & \\
\hline A & 0 & 0 & 0 & 0 & 0 & 0 & 0 & 0 & 0 & 0 & 0 & 0 & 0 & 0 & 0 & 0 & 0 & 0 \\
\hline $\mathrm{C}$ & 0 & 20 & 0 & 0 & 26 & 0 & 0 & 27 & 27 & 27 & 0 & 14 & 26 & 27 & 27 & 0 & 27 & 27 \\
\hline$F$ & 12 & 28 & 0 & 0 & 0 & 0 & 0 & 0 & 10 & 10 & 1 & 1 & 0 & 1 & 6 & 4 & 0 & 33 \\
\hline G & 0 & 1 & 0 & 0 & 0 & 0 & 0 & 0 & 1 & 1 & 0 & 0 & 0 & 0 & 0 & 1 & 0 & 2 \\
\hline NG & 25 & 21 & 0 & 1 & 0 & 0 & 0 & 0 & 12 & 15 & 3 & 5 & 9 & 0 & 7 & 13 & 0 & 47 \\
\hline Total & 37 & 70 & 0 & 1 & 26 & 0 & 0 & 27 & 50 & 53 & 4 & 20 & 35 & 28 & 40 & 18 & 27 & 109 \\
\hline
\end{tabular}

NG, not groupable.

* Numbers correspond to those in table I.

Table IV. Agglutination of boiled cells of different Lancefield groups with different lectins

\begin{tabular}{|c|c|c|c|c|c|c|c|c|c|c|c|c|c|c|c|c|c|c|}
\hline \multirow{2}{*}{$\begin{array}{l}\text { Lancefield } \\
\text { group }\end{array}$} & \multicolumn{17}{|c|}{ Number of strains that agglutinated with each lectin* } & \multirow{2}{*}{ Total } \\
\hline & 1 & 4 & 5 & 7 & 8 & 9 & 10 & 13 & 14 & 15 & 16 & 17 & 19 & 21 & 22 & 23 & 24 & \\
\hline A & 0 & 0 & 0 & 0 & 0 & 0 & 0 & 0 & 0 & 0 & 0 & 0 & 0 & 0 & 1 & 0 & 0 & 1 \\
\hline $\mathrm{C}$ & 0 & 16 & 0 & 0 & 28 & 0 & 0 & 31 & 31 & 31 & 0 & 15 & 27 & 31 & 33 & 0 & 31 & 33 \\
\hline $\mathrm{F}$ & 11 & 70 & 12 & 0 & 0 & 6 & 0 & 0 & 33 & 36 & 0 & 0 & 0 & 1 & 82 & 1 & 0 & 82 \\
\hline $\mathrm{G}$ & 0 & 8 & 1 & 0 & 0 & 0 & 0 & 0 & 2 & 5 & 0 & 0 & 0 & 1 & 9 & 0 & 0 & 9 \\
\hline NG & 30 & 13 & 19 & 0 & 0 & 11 & 1 & 0 & 11 & 14 & 3 & 3 & 5 & 0 & 90 & 9 & 0 & 93 \\
\hline Total & 41 & 107 & 32 & 0 & 28 & 17 & 1 & 31 & 77 & 86 & 3 & 18 & 32 & 33 & 215 & 10 & 31 & 218 \\
\hline
\end{tabular}

NG, not groupable.

* Numbers correspond to those in table I.

results, each agglutinating $14(33 \%)$ of the 42 strains. The $S$. anginosus type strain, belonging to Lancefield group $\mathrm{G}$, agglutinated in the presence of APA, CCL and RSA while the other two (both ungroupable by Lancefield antisera) did not react with any lectin (table V). After trypsinisation of the bacteria, 109 strains, including the $S$. intermedius and the $S$. anginosus type strains, agglutinated in the presence of at least one of the lectins tested (tables III and V). APA gave the highest, number, agglutinating $70(64 \%)$ of the 109 strains (table III). When the bacteria were first boiled at $\mathrm{pH} 2$, agglutination with one or more lectins was observed with 218 strains, including the three type strains (tables IV and V). WGA agglutinated 214 strains $(98 \%)$, whereas PNA reacted with only 107 strains $(49 \%$ ) (table IV). The lectins AMA, AUA, MAA, NPA, SNA, TL and VAA did not agglutinate any of the " $S$. milleri" strains tested, whereas lectins DSA, RPA and DBA reacted only with strains of Lancefield group C (tables II, III and IV).

The specificity of the agglutination was tested in a hapten inhibition test. Agglutination by all the lectins could be inhibited by their respective haptenic carbohydrates which are indicated in table I. Lectins DSA and RPA were also inhibited by D-GalNAc and mucin (results not shown).

Reproducibility testing revealed that lectin patterns were not altered after subculture of the bacteria. However, most strains displayed different agglutination patterns according to their pre-treatment. This phenomenon was also seen with the ATCC type strains (table V). Whereas $S$. constellatus reacted only when the bacteria were boiled, $S$. intermedius reacted after both boiling and trypsin treatment, but a different 
Table V. Lectin agglutination of ATCC type strains after different treatments

\begin{tabular}{|c|c|c|c|c|c|c|c|c|c|c|c|c|c|c|c|c|c|c|}
\hline \multirow{2}{*}{$\begin{array}{l}\text { ATCC } \\
\text { strain }\end{array}$} & \multirow{2}{*}{ Treatment } & \multicolumn{17}{|c|}{ Agglutination with lectins* } \\
\hline & & 1 & 4 & 5 & 7 & 8 & 9 & 10 & 13 & 14 & 15 & 16 & 17 & 19 & 21 & 22 & 23 & 24 \\
\hline \multirow{3}{*}{$\begin{array}{l}\text { S. constellatus } \\
\text { (No. 27823) }\end{array}$} & Untreated & - & - & - & - & - & - & - & - & - & - & - & - & - & - & - & - & - \\
\hline & Trypsinised & - & - & - & - & - & - & - & - & - & - & - & - & - & _- & - & _- & - \\
\hline & Boiled & - & - & - & - & - & - & - & - & - & - & - & - & - & - & + & - & - \\
\hline \multirow{3}{*}{$\begin{array}{l}\text { S. intermedius } \\
\text { (No. 27335) }\end{array}$} & Untreated & - & - & - & - & - & - & - & - & - & - & - & - & - & - & - & - & - \\
\hline & Trypsinised & + & + & - & - & - & - & - & - & + & - & - & - & - & - & - & - & - \\
\hline & Boiled & + & + & - & - & - & - & - & - & + & + & + & + & + & - & + & - & - \\
\hline \multirow{3}{*}{$\begin{array}{l}\text { S. anginosus } \\
\text { (No. 22297) }\end{array}$} & Untreated & - & + & - & - & - & - & - & - & + & + & - & - & - & - & - & - & - \\
\hline & Trypsinised & - & + & - & - & - & - & - & - & + & + & - & - & - & - & - & - & - \\
\hline & Boiled & - & + & - & - & - & - & - & - & - & + & - & - & - & - & + & - & - \\
\hline
\end{tabular}

* Numbers correspond to those in table I.

Table VI. Patterns of lectin agglutination most frequently obtained with untreated (U), trypsin-treated (T) or boiled (B) cells

\begin{tabular}{|c|c|c|c|c|c|c|c|c|c|c|c|c|c|c|c|c|c|c|c|c|}
\hline \multirow{2}{*}{$\begin{array}{c}\text { Pattern } \\
\text { no. }\end{array}$} & \multicolumn{17}{|c|}{ Agglutination with lectins* } & \multicolumn{3}{|c|}{ Number of strains } \\
\hline & 1 & 4 & 5 & 7 & 8 & 9 & 10 & 13 & 14 & 15 & 16 & 17 & 19 & 21 & 22 & 23 & 24 & $\mathrm{U}$ & $T$ & B \\
\hline 1 & - & + & - & - & + & - & - & + & + & + & - & + & + & + & + & - & + & 2 & 10 & 9 \\
\hline 2 & - & + & - & - & + & - & - & + & + & + & - & - & + & + & + & - & + & 1 & 10 & 5 \\
\hline 3 & - & - & - & - & + & - & - & + & + & + & - & - & + & + & + & - & + & 2 & 2 & 8 \\
\hline 4 & - & + & - & - & - & - & - & - & + & + & - & - & - & - & - & - & - & 3 & 10 & 0 \\
\hline 5 & + & - & - & - & - & - & - & - & - & - & - & - & - & - & - & - & - & 13 & 8 & 0 \\
\hline 6 & - & + & - & - & - & - & - & - & - & - & - & - & - & - & - & - & - & 6 & 7 & 0 \\
\hline 7 & + & + & - & - & - & - & - & - & - & - & - & - & - & - & - & - & - & 1 & 10 & 0 \\
\hline 8 & - & - & - & - & - & - & - & - & - & - & - & - & - & - & - & + & - & 3 & 8 & 2 \\
\hline 9 & + & + & - & - & - & - & - & - & - & - & - & - & - & - & + & - & - & 0 & 2 & 10 \\
\hline 10 & - & + & - & - & - & - & - & - & - & - & - & - & - & - & + & - & - & 0 & 4 & 20 \\
\hline 11 & - & - & - & - & - & - & - & - & - & - & - & - & - & - & + & - & - & 0 & 4 & 40 \\
\hline 12 & - & + & + & - & - & - & - & - & - & - & - & - & - & - & + & - & - & 0 & 0 & 7 \\
\hline 13 & - & + & - & - & - & - & - & - & + & + & - & - & - & - & + & - & - & 0 & 0 & 31 \\
\hline 14 & + & - & - & - & - & - & - & - & - & - & - & - & - & - & + & - & - & 0 & 0 & 20 \\
\hline 15 & - & - & + & - & - & - & - & - & - & - & - & - & - & - & + & - & - & 0 & 0 & 9 \\
\hline
\end{tabular}

* Numbers correspond to those in table I.

Table VII. Discrimination given by lectin agglutination patterns obtained after different pre-treatments of the bacteria and in combination with Lancefield grouping among 221 isolates of " $S$. milleri"

\begin{tabular}{|c|c|c|c|c|}
\hline \multirow[b]{2}{*}{$\begin{array}{l}\text { Pre-treatment of the } \\
\text { bacteria or combinations of } \\
\text { pre-treatments }\end{array}$} & \multicolumn{2}{|c|}{ Without Lancefield grouping } & \multicolumn{2}{|c|}{ With Lancefield grouping } \\
\hline & $\begin{array}{l}\text { Number of } \\
\text { groups }\end{array}$ & $\begin{array}{c}\text { Number of groups } \\
\text { containing one } \\
\text { isolate }\end{array}$ & $\begin{array}{l}\text { Number of } \\
\text { groups }\end{array}$ & $\begin{array}{l}\text { Number of groups } \\
\text { containing one } \\
\text { isolate }\end{array}$ \\
\hline Untreated & 17 & 8 & 24 & 10 \\
\hline Trypsin-treated & 37 & 19 & 48 & 25 \\
\hline Boiled at $\mathrm{pH} 2$ & 45 & 22 & 58 & 28 \\
\hline Untreated + trypsin-treated & 60 & 37 & 68 & 42 \\
\hline $\begin{array}{l}\text { Untreated + boiled } \\
\text { Un }\end{array}$ & 72 & 46 & 87 & 48 \\
\hline Trypsin-treated + boiled & 97 & 63 & 109 & 69 \\
\hline Untreated + trypsin-treated + boiled & 118 & 90 & 130 & 97 \\
\hline
\end{tabular}

agglutination pattern was obtained. After trypsinisation, this strain reacted with only three lectins, but after boiling at $\mathrm{pH} 2$, it reacted with five more. The $S$. anginosus type strain gave the same agglutination pattern when trypsin-treated, as the untreated cells. However, after boiling the cells, only WGA gave a positive reaction.
When the bacteria were left untreated, 17 different agglutination patterns were obtained. Trypsinisation of the cells yielded 37 different patterns, 10 of which were identical to those obtained with untreated cells. Agglutination studies with bacterial cells boiled in $0.25 \mathrm{M}$ glycine- $\mathrm{HCl}(\mathrm{pH} 2)$ gave 45 different patterns, seven of which were identical to those obtained with 
trypsin-treated bacteria and five to those obtained with both untreated and trypsin-treated bacteria. The 15 most frequently encountered lectin agglutination patterns are shown in table VI. The number of strains which agglutinated after each treatment are given for all the agglutination patterns. Patterns 1,2 and 3 are specific for strains belonging to Lancefield group C. The other lectin patterns are not specific for one Lancefield group.

Only one strain did not react with any lectin untreated or after either treatment. One strain yielded the same agglutination pattern untreated and after both treatments, and 12, two and 19 strains, respectively, yielded the same pattern with untreated and typsinised cells, with untreated and boiled cells, and with trypsinised and boiled cells.

Combining lectin agglutination with different pretreatments of the bacteria markedly increased the discrimination between isolates (table VII). A combination of lectin agglutination patterns derived from untreated, trypsin-treated and boiled cells yielded 118 different groups, 90 of which contained only one isolate. The combination of lectin agglutination with Lancefield grouping yielded 130 different groups, 97 of which contained only one isolate, whereas Lancefield grouping alone gave only five groups (table VII).

\section{Discussion}

"S. milleri" is a heterogeneous group of bacteria differing in many bacteriological characteristics. ${ }^{8} \mathrm{Re}$ cently, an increasing number of these strains have been recognised as clinically important pathogens. ${ }^{29}$ Therefore, a discriminatory, reproducible and rapid typing method for these bacteria would be helpful as an addition to Lancefield grouping, which distinguishes only four groups (A, C, F and G) and leaves almost $50 \%$ of the strains ungroupable. Moreover, most of the groupable strains belong to group $\mathrm{F}^{6}{ }^{6}$

In this study, the agglutination of 221 isolates of " $S$. milleri" by 25 different lectins was tested. The agglutination patterns were reproducible but differed according to the pre-treatment of the bacteria. With untreated, trypsin-treated and boiled isolates, 42, 109 and 218 isolates, respectively, reacted with at least one lectin, giving rise to 17,37 and 45 different agglutination patterns. When the three agglutination patterns for each strain were considered, 118 different groups were found. In combination with Lancefield grouping of the bacteria, 130 groups were obtained. This indicates that the lectin agglutination assay is highly discriminatory and could be useful for epidemiological investigations. Since 97 of 130 groups contained only one isolate, it is clear that most bacterial isolates studied here possess unique surface structures. When the bacterial surface structures are partially destroyed by trypsin or by boiling in glycine- $\mathrm{HCl}$ at $\mathrm{pH} 2$, some carbohydrate residues dissolve in the buffer while others, previously hidden, then tecome exposed on the surface. Therefore, the agglutination patterns differed according to the pre-treatment of the bacteria. As agglutination by all the lectins could be inhibited by their respective haptenic carbohydrates, the agglutination reactions are specific lectin-carbohydrate bonds.

When the bacteria were first boiled at $\mathrm{pH}$, WGA reacted with almost all strains, whereas without pretreatment and after trypsinisation only five and 40 strains, respectively, agglutinated in the presence of WGA. This was also demonstrated with "large colony type" $\beta$-haemolytic streptococci. ${ }^{28}$ Probably the teichoic acids and the peptidoglycans, which can bind to WGA, ${ }^{30}$ become exposed on the bacterial surface only after boiling at $\mathrm{pH} 2$.

Some of the patterns were specific for strains of Lancefield group C. These patterns are the same as those described earlier among other $\beta$-haemolytic streptococci. ${ }^{28}$ Indeed, the lectins from Datura stramonium (DSA), Robinia pseudoacacia (RPA) and Dolichos biflorus (BDA) agglutinate specifically " $S$. milleri" isolates of group $\mathrm{C}$ as well as those strains belonging to the "large colony type" $\beta$-haemolytic streptococci of group C ${ }^{28}$ However, the lectins WFA, CCL, SSL and SNA II, described as agglutinating specifically $\beta$-haemolytic group C streptococci, ${ }^{28,31}$ also reacted with " $S$. milleri" isolates of other Lancefield groups. The same phenomenon has been observed in studies of the Helix pomatia lectin with " $S$. milleri" and led to the assumption that antigens other than the group-specific C-polysaccharide may be involved in the recognition and binding of the lectin. ${ }^{32}$ Indeed, the "minor antigens" of Ottens and Winkler have been observed in " $S$. milleri" ${ }^{33}$ The groupspecific polysaccharide of Lancefield group C streptococci is a terminal $\alpha$-N-acetyl-D-galactosamine coupled to the poly-L-rhamnose backbone. ${ }^{34}$ Despite the facts that DSA shows specificity towards GlcNAc and that RPA has a complex specificity, they both agglutinate only group $\mathrm{C}$ streptococci, and both are able to bind to the group-specific antigen as the agglutination of both lectins can be inhibited by $0 \cdot 1 \mathrm{M}$ D-GalNAc.

It became clear from the agglutination assays with diverse lectins that, despite their different ecological and pathogenic characteristics, the "minute colony"forming bacteria of the " $S$. milleri" group and the "large colony"-forming streptococci have the same cell-wall structures. Nevertheless, the cell wall is an important virulence factor in many bacteria. It is possible that the cell walls differ in components other than those reacting with the lectins, so these differences cannot be detected by lectin agglutination assays.

Lectin agglutination is cheap, rapid and easy to perform and is highly discriminatory; the results are reproducible-all of which makes it suitable for epidemiological and ecological studies of " $S$. milleri". However, for practical purposes, it is advisable to use only boiled cells and an agglutination assay with only six lectins. When the lectins PNA, APA, GNA, RSA, 
Con-A and DBA are used, $76 \%$ of strains can be divided in 18 groups with different lectin patterns.

\section{References}

1. Guthof O. Über pathogene "vergrunende Streptokokken". Streptokokken-Befunde bei dentogenen Abszessen und Infiltraten im Bereich der Mundhöhle. Zentralbl Bakteriol Parasitenkd Infektionskr Hyg Abt 1 Orig 1956; 166: 553-564.

2. Colman G, Williams REO. Taxonomy of some human viridans streptococci. In: Wannamaker LW, Matsen JM (eds) Streptococci and streptococcal diseases: recognition, understanding and management. New York, Academic Press. 1972: 281-299.

3. Facklam RR. The major differences in the American and British Streptococcus taxonomy schemes with special reference to "Streptococcus milleri". Eur J Clin Microbiol 1984; 3: 91-93.

4. Coykendall AL, Wesbecher PM, Gustafson KB. "Streptococcus milleri", Streptococcus constellatus, and Streptococcus intermedius are later synonyms of Streptococcus anginosus. Int J Syst Bacteriol 1987; 37: 222-228.

5. Whiley RA, Hardie JM. DNA-DNA hybridization studies and phenotypic characteristics of strains within the "Streptococcus milleri" group. J Gen Microbiol 1989; 135: 2623-2633.

6. Whiley RA, Beighton D. Emended descriptions of Streptococcus constellatus, Streptococcus intermedius and Streptococcus anginosus as distinct species. Int J Syst Bacteriol $1991 ; 41: 1-5$.

7. Skerman VBD, McGown V, Sneath PHA. Approved lists of bacterial names. Int J Syst Bacteriol 1980; 30: 225-420.

8. Piscitelli SC, Shwed J, Schreckenberger P, Danziger LH. "Streptococcus milleri" group: renewed interest in an elusive pathogen. Eur J Clin Microbiol Infect Dis 1992; 11: 491-498.

9. Drucker DB, Lee SM. Fatty acid fingerprints of "Streptococcus milleri", Streptococcus mitis, and related species. Int J Syst Bacteriol 1981; 31: 219-225.

10. Drucker DB, Lee SM. Possible heterogeneity of "Streptococcus milleri" determined by DNA mol\% (guanine + cytosine) measurement and physiological characterization. Microbios 1983 ; 38: 151-157.

11. Aluyi HS, Drucker DB. Trimethylsilyl-sugar profiles of "Streptococcus milleri" and Streptococcus mitis. J Appl Bacteriol 1983; 54: 391-397.

12. Lotan R, Skutelsky E, Danon D, Sharon N. The purification, composition, and specificity of the anti-T lectin from peanut (Arachis hypogaea). J Biol Chem 1975; 250: $8518-8523$.

13. Peumans WJ, Nsimba-Lubaki M, Peeters B, Broekaert WF Isolation and partial characterization of a lectin from ground elder (Aegopodium podagraria) rhizomes. Planta $1985 ; 164: 75-82$.

14. Van Damme EJM, Goldstein IJ, Peumans WJ. A comparative study of related mannose-binding lectins from Amaryllidaceae and Alliaceae species. Phytochemistry 1991; 30: 509-514.

15. Peumans WJ, Nsimba-Lubaki M, Carlier AM, Van Driessche E. A lectin from Bryonia dioica root stocks. Planta 1984; 160: $222-228$.
We thank M. Vliegen for his technical assistance. W.J.P. is research director of the Belgian National Fund for Scientific Research (NFWO).
16. Broekaert WF, Peumans WJ, Allen AK. Carbohydrate binding proteins from Datura stramonium seeds. In: Bøg-Hansen TC, Breborowicz J (eds) Lectins, vol 4. Berlin, Walter de Gruyter Co. 1985: 481-489.

17. Kawaguchi T, Matsumoto I, Osawa T. Studies on hemagglutinins from Maackia amurensis seeds. J Biol Chem 1974; 249: 2786-2792.

18. Wantyghem J, Goulut C, Frenoy JP, Turpin E, Goussault Y. Purification and characterization of Robinia pseudoacacia seed lectins. Biochem J 1986; 237: 483-489.

19. Kellens JTC, Peumans WJ. Occurrence of lectins in different strains of Rhizoctonia solani. In: Kocourek J, Freed DJL (eds) Lectins, vol 7. St Louis, Sigma Chemical Co. 1990: $57-62$

20. Kellens JTC, Goldstein IJ, Peumans WJ. Lectins in different members of the Sclerotiniaceae. Mycol Res 1992; 96 : 495-502.

21. Kaku H, Peumans WJ, Goldstein IJ. Isolation and characterization of a second lectin (SNA-II) present in elderberry (Sambucus nigra L.) bark. Arch Biochem Biophys 1990; 277: $255-262$.

22. Cammue BPA, Peeters B, Peumans WJ. A new lectin from tulip (Tulipa) bulbs. Planta 1986; 169: 583-588.

23. Kurokawa T, Tsuda M, Sugino Y. Purification and characterization of a lectin from Wisteria floribunda seeds. $J$ Biol Chem 1976; 251 : 5686-5693.

24. Nagata Y, Burger MM. Wheat germ agglutinin. Molecular characteristics and specificity for sugar binding. $J$ Biol Chem 1974; 249: 3116-3122.

25. Agrawal BBL, Goldstein IJ. Protein-carbohydrate interaction VI. Isolation of concanavalin A by specific adsorption on cross-linked dextran gels. Biochim Biophys Acta 1967; 147: 262-271

26. Etzler ME, Kabat EA. Purification and characterization of a lectin (plant hemagglutinin) with blood group A specificity and Dolichos biflorus. Biochemistry 1970; 9: 869-877.

27. Ziska P, Franz H, Kindt A. The lectin I from Viscum album L. purification by biospecific affinity chromatography. Experientia 1978; 34: 123-125.

28. Kellens JTC, Jacobs JA, Peumans WJ, Stobberingh EE. The agglutination of $\beta$-haemolytic streptococci by lectins. $J$ Med Microbiol 1993; 39: 440-445.

29. Gossling J. Occurrence and pathogenicity of the "Streptococcus milleri" group. Rev Infect Dis 1988; 10: 257-285.

30. Wagner $\mathbf{M}$. Interaction of wheat-germ agglutinin with streptococci and streptococcal cell wall polymers. Immunobiology 1979; 156: 57-64.

31. Slifkin M, Doyle RJ. Lectins and their application to clinical microbiology. Clin Microbiol Rev 1990; 3: 197-218.

32. Köhler W, Nagai T. Reactions of the lectin anti-AHP from the edible snail Helix pomatia with N-acetyl-D-galactosamine of streptococci. Kitasato Arch Exp Med 1989; 62: 107-113.

33. Lütticken $R$, Wendorff U, Lütticken $D$, Johnson EA, Wannamaker LW. Studies on streptococci resembling "Streptococcus milleri" and on an associated surface-protein antigen. J Med Microbiol 1978; 11: 419-431.

34. Uhlenbruck G, Pardoe GI, Prokop O. Untersuchungen zur Spezifität der Helixagglutinine. In: Perlick E, Plenert W, Prokop O (eds) Fortschritte der Hämatologie. Leipzig, Johann Ambrosius Barth. 1970: 41-69. 